\title{
Canine neosporosis: perspectives on pathogenesis and management
}

This article was published in the following Dove Press journal:

Veterinary Medicine: Research and Reports

26 April 2016

Number of times this article has been viewed

\section{Rodrigo C Silva' Gustavo P Machado² \\ 'Department of Pathobiology and Population Medicine, College of Veterinary Medicine, Mississippi State University, Starkville, MS, USA; ${ }^{2}$ Department of Internal Medicine and Surgery of Small Animals, Dr Munhoz Veterinary Hospital, Itápolis, Brazil}

Correspondence: Rodrigo C Silva Department of Pathobiology and Population Medicine, College of Veterinary Medicine, Mississippi State University, 640 Wise Center Drive, Starkville, MS 39762-6100, USA

Tel +l 6623257979

Fax + I 6623254548

Email rsilva@cvm.msstate.edu

\begin{abstract}
Canine neosporosis is a worldwide disease caused by the obligate intracellular parasite protozoan Neospora caninum, manifesting mainly neurological symptoms. $N$. caninum has a heteroxenous life cycle and affects a wide range of warm-blooded animals. The domestic and wild canids are the definitive host of the parasite. They shed oocysts after ingestion of tissue cysts from infected intermediate hosts (ovine, equine, bovine, canine, and many other species), containing bradyzoites, or oocyst-contaminated water and food. The presence of dogs in farms is considered a risk factor for production animals. A wide range of diagnostic methods are currently available, but the most used is serology, ie, indirect fluorescent antibody test specific to the antibody detection in blood serum samples. No vaccine is available, but control strategies should be focused on the vertical and horizontal transmission of the parasite, ie, avoid feeding dogs with raw or undercooked meat, and taking care with water for human and animal consumption. No medicines to control the transplacental transmission are available yet.
\end{abstract}

Keywords: neosporosis, Neospora caninum, pathogenesis, management, dogs

\section{Introduction}

Neospora caninum is an obligate intracellular parasite protozoan that causes neosporosis in a wide range of warm-blooded animals, including domestic and wild animals. Neosporosis is a worldwide emergent disease, ${ }^{1-3}$ and is usually associated with reproductive (ie, neonatal mortality in animals, particularly in dogs and cattle) and neurological (ie, neuromuscular degeneration) disorders and presents progressive evolution, being more severe in young animals. ${ }^{4,5}$ For cattle, it is considered one of the most important causes of infertility, abortion, and neonatal mortality. Sheep can also develop reproductive and neonatal disease, but the economic importance of $N$. caninum in sheep is less clear when compared with cattle. ${ }^{6}$

In Norway, Bjerkås et $\mathrm{al}^{7}$ diagnosed a disease similar to toxoplasmosis, another apicomplexan parasitic disease, in a litter of seven boxer puppies, which presented Toxoplasma gondii-like tissue cysts with no specific antibodies. The new parasite was firstly classified $N$. caninum by Dubey et $\mathrm{al}^{8}$ in the US. These authors isolated and described the disease caused by a protozoan infecting a puppy with clinical signs similar to those reported by Bjerkas et al. ${ }^{7}$ Afterwards, this protozoan was recognized as the causative agent of the disease in dogs, and identified in bovine aborted and mummified fetuses and in calves with neonatal paralysis. ${ }^{9}$ McAllister et al ${ }^{10}$ defined the domestic dog (Canis lupus familiaris) as the definitive host of $N$. caninum, and Gondim et $\mathrm{al}^{2}$ reported the coyote $(C$. latrans) as a wild definitive host of the parasite 
by confirming the sexual stage of the parasite, and oocysts being shed in feces. The absence of information concerning the epidemiology of the parasite has limited the introduction of objective and effective measures to prevent and control the infection significantly over time.

\section{Epidemiology}

Three infective stages characterize the $N$. caninum life cycle: sporozoites within sporulated oocysts (sporulated oocysts present two sporocysts with four sporozoites each), rapidly dividing tachyzoites, and slowly proliferating bradyzoites within tissue cysts (Table 1). ${ }^{11-13}$ Oocysts are the environmentally resistant stage of the parasite shed in the definitive host feces, which can survive for months to years in the environment. Tissue cysts have a huge cyst wall that protects the bradyzoites from the hostile extracellular environment formed during the host immune response. This form is observed mainly in muscle and the central nervous system (CNS). Each tissue cyst may have 20-100 bradyzoites. Bradyzoites survive at $4{ }^{\circ} \mathrm{C}$ for over 14 days, ${ }^{13,14,18}$ and are also resistant to pepsin and trypsin digestion. Tachyzoites can be found free in organic fluids and in a parasitophorous vacuole (PV) placed at the cytoplasm of the host cell, but are particularly vulnerable to the harmful effects of extracellular maintenance and rapidly lose their capacity for invasion. ${ }^{4}$ They can actively penetrate membranes of a wide range of nucleated cells, which suggests low host-cell specificity. ${ }^{18,19}$ Tachyzoites multiply by endodyogeny, ${ }^{20}$ and promote the expansion of the PV up to the cell lysis.

$N$. caninum is a heteroxenous parasite. ${ }^{21} \operatorname{Dog}(C$. lupus familiaris) is considered the definitive nonwild host of the parasite, ${ }^{10,22}$ whereas coyote $(C$. latrans $),{ }^{2}$ Australian dingo (C. lupus dingo $),{ }^{23}$ and gray wolf $(C \text {. lupus })^{24}$ are the definitive wild hosts. A wide range of intermediate hosts has been reported (Table 2$).{ }^{25}$

Many aspects of the $N$. caninum life cycle are still unknown, mainly concerning the sexual stage of the parasite evolution. ${ }^{39}$ More studies are necessary to clarify the entire enteroepithelial cycle and to elucidate the interaction between the dog and the parasite in natural, not experimental, infection.

$N$. caninum can be transmitted in two ways: vertically and horizontally. Vertical transmission happens during terminal stages of gestation (transplacental transmission with fetal infection) or postnatally, by the transmission of tachyzoites via milk (transmammary transmission). ${ }^{3,52}$ In horizontal transmission, the infection occurs postnatally after ingestion of water containing sporulated oocysts, or of infected tissues (raw or undercooked meat, fetal membranes) of intermediate hosts with tissue cysts or contaminated with sporulated oocysts. ${ }^{20}$ Fecal trans-

Table I Structural and morphological characteristics of Neospora caninum stages

\begin{tabular}{|c|c|c|c|c|c|}
\hline Stage & Structure & Size (length $\times$ width) & Reference & Morphology & Comments \\
\hline \multirow[t]{4}{*}{$\begin{array}{l}\text { Oocyst } \\
\text { (sporulated) }\end{array}$} & - & $\sim 10.6-12.4 \times 10.5-12 \mu \mathrm{m}$ & Dubey et $\mathrm{al}^{14}$ & $\begin{array}{l}\text { Thin, colorless, ovoid, } \\
\text { or ellipsoidal }\end{array}$ & $\begin{array}{l}\text { Environmentally resistant form of the } \\
\text { parasite }\end{array}$ \\
\hline & Oocyst wall & $\sim 0.6-0.8 \mu \mathrm{m}$ thick & Dubey et al ${ }^{14}$ & $\begin{array}{l}\text { Colorless, bilayered, } \\
\text { smooth-surface walls }\end{array}$ & $\begin{array}{l}\text { The oocyst wall encompasses two } \\
\text { sporocysts }\end{array}$ \\
\hline & Sporocyst & $\sim 7.4-9.4 \times 5.6-6.4 \mu \mathrm{m}$ & Dubey et $\mathrm{al}^{14}$ & & $\begin{array}{l}\text { Each sporocyst contains four sporozoites } \\
\text { and a residuum }\end{array}$ \\
\hline & Sporozoite & $5.8-7 \times 1.8-2.2 \mu \mathrm{m}$ & Dubey et al ${ }^{14}$ & Elongated & \\
\hline \multirow[t]{3}{*}{ Tissue cyst } & - & $\sim 30-107 \mu \mathrm{m}$ (diameter) & $\begin{array}{l}\text { Dubey et al } \\
\text { Barr et al }{ }^{16} \\
\text { Dubey et } \text { al }^{17}\end{array}$ & Round and oval & $\begin{array}{l}\text { Bradyzoites and tachyzoites have conoids, } \\
\text { numerous micronemes (size } 232 \times 58 \mathrm{~nm} \text { ), } \\
\text { rhoptries ( } 45 \mathrm{~nm} \text { wide), amylopectin, and }\end{array}$ \\
\hline & Cyst wall & $\sim 0.5-4 \mu \mathrm{m}$ thick & $\begin{array}{l}\text { Dubey et al }\left.\right|^{14} \\
\text { Speer et } \mathrm{al}^{18}\end{array}$ & $\begin{array}{l}\text { Smooth, irregular, wavy } \\
\text { contour in tissue sections, } \\
\text { but without protrusions. } \\
\text { Septa and a secondary } \\
\text { tissue cyst wall are absent }\end{array}$ & nucleus \\
\hline & Bradyzoite & $\sim 4.5-8 \times 1.2-1.9 \mu \mathrm{m}$ & $\begin{array}{l}\text { Barr et } \mathrm{al}^{16} \\
\text { Speer et } \mathrm{al}^{18} \\
\text { Dubey et al }{ }^{14} \\
\text { Dubey et al }{ }^{17}\end{array}$ & $\begin{array}{l}\text { Slender, elongated with a } \\
\text { subterminal nucleus, slightly } \\
\text { longer than tachyzoites }\end{array}$ & \\
\hline Tachyzoite & Tachyzoite & $\sim 3-7 \times 1-2 \mu \mathrm{m}$ & $\begin{array}{l}\text { Dubey et a } \mathbf{l}^{14} \\
\text { Speer et } \mathrm{al}^{18}\end{array}$ & Ovoid, lunate, or globular & \\
\hline
\end{tabular}


Table 2 Definitive and intermediate hosts in neosporosis

\begin{tabular}{|c|c|c|c|c|}
\hline $\begin{array}{l}\text { Epidemiological } \\
\text { classification }\end{array}$ & Common name & Scientific name & Area & References \\
\hline \multirow[t]{4}{*}{ Definitive host } & Dog & Canis lupus familiaris & Non-W & $3,6-8,10-13,39,20-22,26-32,34-38,40$ \\
\hline & Coyote & Canis latrans & W & $2,6,39,41$ \\
\hline & Australian dingo & Canis lupus dingo & W & 23,39 \\
\hline & Gray wolf & Canis lupus & W & $6,24,39$ \\
\hline \multirow[t]{41}{*}{ Intermediate host } & Dog & Canis lupus familiaris & Non-W & $3,6,10,12,13,20-22,27,35,41$ \\
\hline & African wild dog & Lycaon pictus & W & 39 \\
\hline & Golden jackal & Canis aureus & w & 39 \\
\hline & Hoary fox & Pseudalopex vetulus & w & 39,42 \\
\hline & Red fox & Vulpes vulpes & W & $6,39,41$ \\
\hline & Raccoon & Procyon lotor & W & 39,41 \\
\hline & Coyote & Canis latrans & W & $2,6,39,41$ \\
\hline & Gray wolf & Canis lupus & W & 6,24 \\
\hline & Cattle & Bos taurus & Non-W & $5,6,11,15,16,32,34,43,44,46-59,92$ \\
\hline & Buffalo & Bubalus bubalis & Non-W & $6,26,45,59-65$ \\
\hline & European bison & Bison bonasus bonasus & Non-W & 39 \\
\hline & Sheep & Ovis aires & Non-W & $6,63,66-71$ \\
\hline & Goat & Capra hircus & Non-W & $6,63,67,69,70,72-74$ \\
\hline & Pig & Sus scrofa & Non-W & 6 \\
\hline & Horse & Equus caballus & Non-W & 75,76 \\
\hline & Donkey & Equus asinus & W & 77 \\
\hline & Camel & Camelus dromedarius & w & 6 \\
\hline & Capybara & Hydrochoerus hydrochaeris & W & 6 \\
\hline & Rat & Rattus norvegicus & Non-W & $6,39,41$ \\
\hline & House mouse & Mus musculus & Non-W & $6,39,41$ \\
\hline & Vole & Microtus arvalis & W & 6 \\
\hline & Water vole & Arvicola terrestris & w & 6 \\
\hline & Rabbit & Oryctolagus cuniculus & w & 6,54 \\
\hline & Hare & Lepus europaeus & W & 6,39 \\
\hline & Egyptian mongoose & Herpestes ichneumon & w & 39 \\
\hline & Cat & Felis catus & Non-W & 6,78 \\
\hline & Feral cat & Felis silvestris & W & 6 \\
\hline & Eurasian lynx & Lynx lynx & W & 6,39 \\
\hline & Iberian lynx & Lynx pardinus & W & 6 \\
\hline & Diverse deer species & - & W & $6,39,41$ \\
\hline & White rhinoceros & Ceratotherium simum & W & 39,41 \\
\hline & Llama & Llama glama & Non-W & 6 \\
\hline & Alpaca & Vicugna pacos & Non-W & 79 \\
\hline & Sea otter & Enhydra lutris neresis & $M$ & 6,39 \\
\hline & Spotted seal & Phoca largha & $M$ & 6,39 \\
\hline & Sparrow & Passer domesticus & $M$ & 6 \\
\hline & Chicken & Gallus gallus domesticus & Non-W & 6 \\
\hline & Pigeon & Columba livia & Non-W & 80 \\
\hline & Common raven & Corvus corax & Non-W & 6,39 \\
\hline & Hooded crow & Corvus cornix & Non-W & 81 \\
\hline & Western jackdaw & Corvus monedula & Non-W & 81 \\
\hline
\end{tabular}

Abbreviations: $\mathrm{W}$, wild area; non- $\mathrm{W}$, nonwild area; $\mathrm{M}$, marine area.

mission (oocysts) appears to be less important than carnivorism. ${ }^{6}$

After ingestion, sporulated oocysts or tissue cysts excyst and release sporozoites and bradyzoites, respectively, into the duodenum lumen. In the intestinal epithelium, sporozoites and bradyzoites transform into tachyzoites, undergo a phase of multiplication, possibly in the mesenteric lymph nodes, ${ }^{11}$ reach the bloodstream, and disseminate to gravid uterus, ${ }^{11}$ and many cell types, ie, CNS cells, vascular endothelial cells, myocytes, hepatocytes, renal cells, alveolar macrophages, and placental trophoblasts, ${ }^{14,43}$ invade the cells and start the multiplication, causing severe lesions on the affected tissues. If the host immune response is active, the extracellular environment turns hostile to the parasite; tachyzoites differentiate to 
bradyzoites and form tissue cysts (asexual stage) in intermediate hosts (chronic stage of the infection). ${ }^{20,25,27,82}$

The recrudescence of the disease for any suppressive factor promotes alterations in host immunity, causing immunomodulation or immunosuppression, the conversion of bradyzoites to tachyzoites, and the rupture of the tissue cysts. This process releases bradyzoites, which reactivate the infection. ${ }^{32,83}$ This is well documented to occur in pregnant animals, causing fetal infection. ${ }^{20,82,84}$

In definitive hosts, tachyzoites transform in merozoites, ie, macrogametes and microgametes, into the intestinal epithelium, undergo merogony (sexual stage), and form a zygote. Zygotes, or nonsporulated oocysts, are released at the intestinal lumen, and shed up to 1 million to the environment with the host feces ${ }^{20,25} 2-30$ days after ingestion. ${ }^{3,40}$ The amount and duration of oocysts shed may be highly variable, due to parasite load ingested, strain, host immunity, and infective stage of the parasite. The nonsporulated oocysts become sporulated and orally infectious outside the host in proper environmental conditions (oxygen concentration, humidity, and temperature) in 1-5 days. . $^{10,85}$

No breed predisposition or differential sex susceptibility to neosporosis in dogs is known, ${ }^{33}$ but age can be a risk factor. Adult dogs shed fewer oocysts than puppies following primary exposure, and puppies may also develop reexcretion after new challenge. ${ }^{36}$

Some important factors to be considered when reporting $N$. caninum infection and disease are the infective form of the parasite, strain virulence, parasite load, and immunity status of the host. $N$. caninum can cause serious disease in cattle and dogs, and occasionally in other animals. ${ }^{6}$

$N$. caninum antibodies have been detected in dogs from North, Central, and South America, Europe, South Africa, Asia, and Oceania. ${ }^{27,51}$ The frequency ranges from 5.8\% (six of 104$)^{29}$ to $12.9 \%(21 \text { of } 163)^{28}$ in England, $5.5 \%$ (19 of 344$)$ to $23.6 \%$ (36 of 152 ) in the Netherlands, ${ }^{32} 7.1 \%$ (14 of 198 ) to $31.3 \%$ (15 of 48) in Japan, ${ }^{31}$ and 0 to $19.2 \%$ in the Czech Republic, according to the use of these dogs (4.7\% army, 0 police, $2.6 \%$ private, and $19.2 \%$ shelter dogs).${ }^{37}$ These data emphasize the epidemiological importance of canine neosporosis, and highlight neosporosis as a differential diagnosis in pet clinics for dogs affected by neurological diseases, since the parasite can stay in the environment where the definitive host sheds the oocysts in their feces. ${ }^{37}$

Wouda et $\mathrm{a}^{32}$ suggested that once dogs and cattle live in the same farm, the chances of the infection in cattle increase. Neither Liu et $\mathrm{al}^{63}$ nor Paiz et $\mathrm{al}^{71}$ observed the pasturing system to be a significant risk factor for goats. In herbivorous creatures, $N$. caninum is the major cause of abortion in both dairy and beef cattle, ${ }^{6}$ but lactogenic transmission can also occur and be important, ${ }^{49,50}$ and should be considered and demonstrated in further studies under natural circumstances in calves or dogs. ${ }^{41}$

Low levels of horizontal transmission in cattle were also observed by Hietala and Thurmond ${ }^{47}$ and Davison et al, ${ }^{46}$ but the importance of this route should not be underestimated, mainly due to the maintenance of the parasite in regional herds. ${ }^{49}$ Worldwide seroprevalence ranges a lot in beef and dairy cattle and buffaloes. In buffaloes, it is $\sim 48 \%$ compared to $16.1 \%$ for dairy cattle and $11.5 \%$ for beef cattle. ${ }^{65}$ This high seroprevalence has ranged from $1.5 \%$ (three of 200) in southern Vietnam ${ }^{45}$ and 3.8\% (four of 105) in the Philippines ${ }^{53}$ to $88 \%$ (169 of 192) in Brazil ${ }^{62}$ and $88.3 \%$ (424 of 480 ) in Australia. ${ }^{59}$

In South America, seroprevalence in dairy cattle has ranged from $10.62 \%$ (66 of 121 ) in Brazil $^{56}$ to $20.3 \%$ in Argentina. ${ }^{58}$ In addition, Fort et $\mathrm{al}^{58}$ observed that dairy cattle had a 3.1-fold higher risk of contracting the parasite through horizontal transmission than beef cattle in Argentina.

In small ruminants, prevalence ranges according to region and species. In goats, prevalence has ranged from $0.4 \%$ (four of 1,060) in Poland ${ }^{73}$ and $0.9 \%$ (four of 464 ) in South Korea $^{74}$ to $19.7 \%$ (182 of 923) in São Paulo, Brazil ${ }^{72}$ and $23.6 \%$ (21 of 89 ) in the Philippines. ${ }^{53}$ In sheep, it has ranged from $0.6 \%$ (four of 640 ) in New Zealand $d^{55}$ and $1.8 \%$ (seven of 409) in Rio Grande do Norte, Brazil ${ }^{66}$ to $59.2 \%$ (353 of 596) in São Paulo, Brazil ${ }^{71}$ and 63\% (214 of 339) in the north of Jordan. ${ }^{67}$ This observed scenario corroborates with the comparisons between species predispositions made by Nasir et al, ${ }^{69}$ Anastasia et al, ${ }^{70}$ and Liu et al, ${ }^{63}$ which indicated sheep to be more likely susceptible to $N$. caninum infection than goats. In addition, the presence of dogs and bad conditions of hygiene are important risk factors that contribute to the infection in these species. ${ }^{63,71}$

\section{Pathogenesis}

The pathogenesis of neosporosis depends on the balance between the capacity of the tachyzoite to penetrate and multiply inside the cells and the host to impede the parasite proliferation. The cell-invasion process has two different steps - the adhesion to the host-cell surface and penetration to the cell ${ }^{86}$ - which may take no more than 5 minutes. ${ }^{43}$ Adhesion, the initial step, is mediated by low-affinity contact, which induces the secretion of microneme-content proteins. In this way, a more specific ligation to the host-cell surface occurs and finally the invasion. For that, adequate receptors 
at the host-cell surface are required to provide enough signals for the invasion of the parasite into the cell cytoplasm. ${ }^{86}$

In order to initiate host-cell invasion, tachyzoites reorient themselves perpendicularly to the host cell-surface membrane and enter the cytoplasm by advancing anterior end first, until they are located in the cytoplasm, enclosed by the PV. Invasion is an active process requiring metabolic energy solely on the part of the parasite, but not on the part of the host cell. ${ }^{83}$

$N$. caninum tachyzoites interact with the host cell by highly conserved apicomplexan mechanisms. In contrast to other genera, $N$. caninum can recognize one or more host cell-surface receptors responsible for the initial adhesion and invasion. ${ }^{86}$ The surface of $N$. caninum tachyzoites exhibits considerable differences from $T$. gondii with regard to surface carbohydrate content, ${ }^{83}$ as well as the interaction of host organelles and scavenging of nutrients. ${ }^{4}$

Once inside, the parasite induces metabolic alterations in the host, which favor its maintenance..$^{43}$ Both parasites reorganize the host microtubular cytoskeleton and attract endoplasmic reticulum, mitochondria, lysosomes, multivesicular bodies (temporary storage compartments enriched in sphingolipids and cholesterol at the intersection of the endocytic and exocytic pathways), and Golgi vesicles to their PV, but in N. caninum infection the host endoplasmic reticulum gathers around the PV, not physically associating with the vacuolar membrane. The parasite attracts the host Golgi apparatus to its PV, surrounding it, but induces less fragmentation into ministacks than T. gondii. ${ }^{4.87}$ Based on that, they scavenge cholesterol from organelles, store it in lipid bodies, and salvage sphingolipids from host Golgi vesicles, sequestering them into their PV; they also attract host mitochondria to their PV, retain these organelles close to the vacuolar membrane, and use the host mitochondria to obtain energy for their benefit; both parasites manipulate the host cell and exploit mammalian resources. These processes are highly conserved in both parasites. ${ }^{4}$

The parasite must invade the host cell to avoid the host immune response. One of these immune mechanisms is the $\mathrm{CD}^{+}{ }^{+}$T-cell response. Jordan and Hunter ${ }^{88}$ emphasized that the $\mathrm{CD} 8^{+} \mathrm{T}$-cell population participates in a protective mechanism used by the host in infections caused by apicomplexan protozoa. $\mathrm{CD} 8^{+} \mathrm{T}$ cells can work as a cytotoxic $\mathrm{T}$ lymphocyte or as cytokine-secreting cells. Many factors influence the generation of $\mathrm{CD} 8^{+} \mathrm{T}$ cell responses, including such cytokines as IL-2 and IL-12, which contribute to T-cell expansion, survival, and the acquisition of effector function. ${ }^{89}$ The participation of this immune cell in host protection is well known to the $T$. gondii infection, but recently Correia et a ${ }^{90}$ observed that the production of IFN $\gamma$ is also a predominant host-protective mechanism conferred by $\mathrm{CD} 8^{+} \mathrm{T}$ cells in the course of neosporosis, as observed in toxoplasmosis. This response and the humoral immune response work together on containing the infection.

Usually, a prepatent period of 5-8 days after ingestion of tissue cysts can be observed in the intestinal form of the disease, but little is known about cysts' localization in the organ or about the affected structures. ${ }^{21} \mathrm{~N}$. caninum can produce necrotic lesions, which are detectable in a few days; it causes cell death by the active multiplication of the tachyzoites, and can induce neuromuscular diseases in dogs and other species by the destruction of a large number of neuronal cells, ie, cranial and spinal nerves, which affect the nerve-impulse conductibility among the cells. ${ }^{1}$

\section{Clinical signs and diagnosis}

In general, neosporosis is asymptomatic in adult and older dogs. ${ }^{21,40}$ More severe and frequent infections occur in young dogs (age less than 6 months old). The clinical signs are usually general and the same as observed in toxoplasmosis, but neurological and muscular abnormalities predominate, ${ }^{33}$ as forelimbs paralysis. In younger puppies, it is normal to observe clinical signs starting at 3-9 weeks old. Forelimb atrophy and gradual muscular rigidity are the most important clinical signs that differentiate neosporosis from those other disorders causing paralysis; even so, hind limbs are more severely affected than forelimbs. The paralysis progresses to rigid contracture of the muscle from the affected limbs. This arthrogryposis results in a scar formation on these muscles, due to injury at the lower motor neuron and myositis. Articular deformation and joint curvature (genu recurvatum) can occur in some puppies, ${ }^{30}$ followed by cervical weakness, dysphagia, megaesophagus, and death. ${ }^{8,25,26}$ Dogs remain in an alert status, paralyzed, and require special care for months. ${ }^{25}$ In addition, severe diarrhea and incoordination, multifocal pulmonary consolidation and necrosis to the necropsy (necrotic and purulent bronchopneumonia), fibrinohemorrhagic enteritis (villous atrophy and crypt hyperplasia in the jejunum and ileum), myocarditis, and nonpurulent encephalitis may occur in young puppies. ${ }^{40}$

It is more probable that dogs over 6 months old can develop the disease by the reactivation of a latent chronic infection. Adult dogs typically develop polymyositis and/or meningoencephalomyelitis, with clinical signs related to the multifocal lesions in the CNS, mainly in the cerebellum; on the other hand, myocarditis, dermatitis, pneumonia, diffuse peritonitis with peritoneal effusion, and multifocal dissemination can occur but are less common, as a result of higher 
tachyzoite dissemination. ${ }^{25}$ These dogs may be obtunded and develop ataxia, circling, head tilt, nystagmus, hypermetria, head tremors, delayed placing reactions, abnormal cranial nerve function, anisocoria, depressed segmental reflexes, tetraparesis, cervical hyperesthesia, and seizures. ${ }^{20}$ In the chronic stage, most animals remain asymptomatic. However, females may have immunosuppression and reactivate the infection during gestation. In this way, bradyzoites switch back to tachyzoites, cross the placenta, and infect the fetus. ${ }^{82,84}$

In buffaloes, naturally occurring disease is rare, but abortion has been reported in animals that have contact with dogs $(60.3 \%),{ }^{60}$ which highlights the role of dogs in the epidemiological chain of neosporosis for production animals.

Neosporosis should be considered when hyperesthesia, muscle swelling, or atrophy is observed at the clinical exam. Dogs of any age can die by CNS or muscular inflammation. ${ }^{25}$ Neurological disorders in dogs have many causes, and neosporosis should be included on the differential diagnosis. Focal lesions have been reported in the brain and spinal cord of a 6-year-old dog with severe mononuclear cell infiltration (large numbers of T lymphocytes and B lymphocytes, and small numbers of macrophages) of the nerve roots of the cauda equina and of the lumbar nerve roots. Necrotizing cerebellitis and hepatitis were also observed. ${ }^{38}$

Epidemiological history and clinical findings can help the diagnosis of suspected neosporosis, as well as the control and prevention of the disease. The findings observed on complete blood count and serum biochemistry panel are also suggestive, but should not be used to confirm the infection. Normal complete blood count with mild nonregenerative anemia, mild eosinophilia, or monocytosis can be observed; nucleated cells are predominantly nondegenerated to mildly degenerated neutrophils. Myositis can cause high alanine aminotransferase values, and hyperglobulinemia can also be observed. The number of nuclear cells in cerebrospinal fluid may be over 1,000 cells $/ \mu L$. Protein concentration can also be increased. ${ }^{20}$

Image diagnosis can also help with the extent of the lesions, ie, radiography (diffuse interstitial pattern in dogs with pneumonia), magnetic resonance imaging, and ultrasonography (cerebellar atrophy in dogs with cerebellar signs), ${ }^{20}$ but with limited contribution. No pathognomonic findings have been reported for neosporosis.

Parasite detection by direct and/or indirect methods is of high importance for the diagnosis and prognosis of the disease and prevention and control of the infection in urban, rural, and wild areas. The available methodologies allow clinicians and researchers to amplify knowledge about classical and molecular epidemiology and pathogenesis of the disease, evaluate the efficacy of available and future drugs used to treat the clinical signs, and adopt measures to avoid dissemination of the parasite.

Direct methods consist in the visualization of oocysts, tissue cysts, or tachyzoites, stained or not, by light microscopy, histopathology, immunohistochemistry, in vitro cell culture and in vivo isolation by gerbil and/or mouse bioassay, fecal flotation of dog feces, and molecular methods, ie, polymerase chain reaction (PCR). ${ }^{40,91,92}$ Among these, each test can provide some type of information not provided by another, ie, histopathology and immunohistochemistry can determine the extension and severity of the lesion in a tissue, whereas molecular methods can just detect the presence/ absence and amount of parasite DNA.

The limit of detection, sensitivity, specificity, and positive and negative predictive values of each test are a crucial part of standardization, and very important to offer an accurate tool for the diagnostic routine. Light microscopy is the cheapest and quickest method that can be used by clinicians, but has limited sensitivity and requires experience in characterizing the infective stages of the parasite, which can be misinterpreted as another apicomplexan. In the same way, cell-culture and gerbil/mouse isolation allow isolation of the parasite, but the results should be confirmed by another technique more specific for identification of the parasite. Both isolation techniques are laborious, require specific technical personnel to handle the animals or cell lines to control other types of infection in a closed system, and require specific infrastructure to maintain the animals and cells under ethical conditions, which all increase the costs. One drawback of both methods is limit of detection. Depending on the sample, the parasite isolation in samples with low parasite load or avirulent or less virulent strains may be difficult. Even if possible, it may still take a minimum of 20-30 days to get results.

Fecal flotation, with sugar or zinc sulfate solutions, is the best technique to isolate $N$. caninum oocysts in dog feces, but it is laborious and may take some time to run. Another limitation is that dogs presenting clinical signs do not shed oocysts, resulting in negative findings. ${ }^{20}$ This technique has high epidemiological value. The cost is not high, but the clinical value for a clinician is limited.

Histopathology and immunohistochemistry are highly recommended in reproductive problems, ie, abortion and fetal lesions, and have been used with molecular techniques. Their sensitivity and specificity will depend on a good target, antibodies, microscope, and an experienced technician to 
provide an accurate evaluation and conclusion. The cost is usually higher than the methodologies reported earlier, but the results are much more conclusive concerning the extent and severity of the lesions.

Molecular methods are considered to have the best sensitivity and specificity, but are too relative. The sensitivity and specificity of these tests are linked to the standardization of the technique, type of sample, stage of the infection, targeted region, and all reagents used. A well-standardized methodology can detect down to just one copy of DNA present in the analytes, but methodologies with problems can fail to detect the parasite or misdiagnose $N$. caninum infection. Corroborating this, van Maanen et $\mathrm{al}^{13}$ observed low agreement between the majority scores of immunohistochemistry and PCR methods (single or nested) in bovine fetal tissues on an interlaboratory comparison in Europe, with false-positive PCR results indicating contamination problems in some instances. The authors strongly linked this problem to the DNA-extraction methods, which could have been optimized and improved the performance of the test. In this way, quality control is an important point in choosing tests or labs to run the samples. Quality control may increase the price of a test, but it also improves the accuracy of the results.

On the other hand, Baszler et $\mathrm{al}^{94}$ and Sanchez et $\mathrm{al}^{95}$ observed $97 \%$ and $85 \%$ agreement, respectively, between immunohistochemistry and a well-standardized PCR protocol in formalin-fixed paraffin-embedded brain tissue of bovine fetuses. They also observed $88 \%$ agreement for fresh tissues.

The wide range of molecular targets allows a wide range for application of molecular techniques, ie, DNA, parasite-load measurement, parasite detection in very low concentrations, exploration of the population evolution of the parasite, analysis of the likelihood of the detected parasites with those from the same and other areas, and characterization of the isolates. In this way, different methodologies have been developed, ie, quantitative real-time PCR, random fragment-length polymorphism PCR, and the use of multilocus microsatellite typing of ten microsatellites for molecular genotyping, which allowed Campero et $\mathrm{al}^{92}$ to identify the isolate NC-Argentina LP1 as a unique genetic pattern, different from all reported isolates.

Differently from direct methods, indirect methods include serological tests by immunoblotting and detection of the indirect response of the host (specific antibodies) to the parasite challenge. ${ }^{33,96-98}$ Routine antemortem diagnosis is usually based on and relies on serology, because organisms are not easily found by cytological examination (Romanowsky or unstained slides), and once found can be misdiagnosed with other apicomplexan parasites, ie, T. gondii or Hammondia heydorni. The limitation of serology is related to the physiopathology of the disease. Usually, antibody levels take 2-3 weeks of infection to be detectable. Antibody research is highly recommended for screening infection in a population, mainly in a herd, and in individual patients to analyze the response of the immune system. The presence of $N$. caninum antibodies in serum samples confirms the parasite exposition, but not the disease. Once detectable, rising titers (usually, fourfold increased titers in 15-30 days' paired serology) can be identified in acutely, not chronically, infected dogs. ${ }^{20}$ Usually, dogs shedding oocysts do not present detectable antibodies.

The indirect fluorescent antibody test (IFAT), ${ }^{8} \mathrm{Neospora}$ agglutination test, ${ }^{98}$ and enzyme-linked immunosorbent assay (ELISA) ${ }^{44,96}$ are the most used techniques for $N$. caninumantibody research. IFAT was the first serological test used. ${ }^{8}$ It has been used extensively for diagnosis of the infection in dogs, is considered a gold-standard test, ${ }^{48}$ and used in epidemiological studies for domestic and wild animals. ELISA and IFAT are usually used to detect $N$. caninum infection in adult animals and herds, and both are also considered complementary techniques in the diagnosis of neosporosis. ${ }^{96}$ Western blotting is usually recommended to confirm uncertain results in valuable samples. ${ }^{99,100}$ In addition, avidity tests are useful for investigating the route of $N$. caninum transmission in herds by differing acute and chronic infections. ${ }^{100,10}$ Again, performance (sensitivity, specificity, and positive and negative predictive values) can range among laboratories, and costs are directly linked to the performance of the tests. Usually, costs for a test or retest are low, but can increase in a periodic control in a herd or large population.

Alvarez-Garcia et al ${ }^{100}$ compared ten commercial indirect or competitive available ELISA tests for bovine neosporosis and obtained excellent sensitivities (95.8\%-100\%, except the IDEXX rum iELISA test, with $85.9 \%$ ) and specificities (93\%-100\%, except the VMRD cELISA test, with 65\%), but almost perfect agreement among all tests (80\%-90\%), as observed by Campero et $\mathrm{al}^{57}$ comparing IFAT and immunoblotting (considered relative standards of comparison), and p38 ELISA (97\%), which resulted in 97.8\% sensitivity and $99.5 \%$ specificity. Björkman et al ${ }^{101}$ observed moderateto-substantial agreement among four European laboratories using IgG-avidity ELISA tests to differentiate acute and chronic bovine neosporosis. On the other hand, Waldner et $\mathrm{al}^{102}$ observed good agreement (76\%) between two commercial ELISA kits, but higher than comparing each test to a commercial direct agglutination test (46\% and 60\%). 
In this way, laboratorial findings are of fundamental importance and make a contribution to the diagnosis of the infection and disease, but should be linked to clinical signs to have enough conclusive information for the treatment of each animal and epidemiological information to adopt adequate measures for prevention and control of the infection. Epidemiological, molecular, and physiopathological information obtained from routine tests and research will help to amplify knowledge about the disease, hostparasite interaction, and the disease's relationship with the environment.

\section{Treatment, prevention, and control}

Treatment of neosporosis is usually difficult and temporarily, partially, or completely ineffective. Long periods ( $>8$ weeks) of treatment may be required. The treatment of dogs with neurological signs is too long, and has a poor prognosis. Treatment is most effective in early stages, before muscular contracture has occurred. ${ }^{103}$ For cutaneous neosporosis, it seems to be more effective. Clindamycin is the primary drug used to treat canine neosporosis. ${ }^{20}$ It is the only lincosamide that possesses additional antiprotozoal activity. Therefore, it is effective against $N$. caninum tachyzoites. The combination of clindamycin and sulfonamide is highly effective against neosporosis. In addition, the synergistic action of sulfonamides and pyrimethamine enhances the antiprotozoal effects. ${ }^{104,105}$ Clindamycin affects the multiplication of $N$. caninum tachyzoites, but is thought to have little or no effect on bradyzoites. ${ }^{106}$ In this way, tissue cysts may persist with even $\sim 2$ months of treatment, and treatment of chronic neosporosis by exposing bradyzoites to the immune response should be considered and researched.

Usually, most of the protocols used to treat neosporosis focus on the control of the clinical manifestations, ${ }^{107}$ rather than the parasitological cure. The most used protocols include clindamycin $7.5-15 \mathrm{mg} \cdot \mathrm{kg}^{-1}$ per os (PO [orally]) or subcutaneously every 8 hours for 4-8 weeks, trimethoprimsulfonamide $15-20 \mathrm{mg} \cdot \mathrm{kg}^{-1} \mathrm{PO}$ every 12 hours for 4-8 weeks, or pyrimethamine-sulfonamide $5-30 \mathrm{mg} \cdot \mathrm{kg}^{-1} \mathrm{PO}$ every 12 hours for $4-8$ weeks. ${ }^{25}$ Other protocols indicated by Sykes $^{20}$ consist of the same drugs with different doses and frequency, ie, clindamycin $10-12 \mathrm{mg} \cdot \mathrm{kg}^{-1} \mathrm{PO}$ every 8 hours for 4 weeks, trimethoprim-sulfonamide $15 \mathrm{mg} \cdot \mathrm{kg}^{-1}$ PO every 12 hours for 4 weeks, pyrimethamine $1 \mathrm{mg} \cdot \mathrm{kg}^{-1}$ PO every 24 hours for 4 weeks, or ponazuril $20 \mathrm{mg} \cdot \mathrm{kg}^{-1} \mathrm{PO}$ every 24 hours for 4 weeks. Treatment should be continued as long as clinical improvement is occurring. ${ }^{20}$

If one member of littermates has neosporosis, all members should be checked for $N$. caninum antibodies, and all those testing seropositive should be treated. The use of immunosuppressive drugs should be avoided in seropositive puppies. ${ }^{20}$ The parasite can be transmitted multiple times from the infected female dog to her offspring, because no preventive treatment is available. ${ }^{12}$

Dogs should never have access to bovine placental materials, dead calves, fetal membranes, aborted fetuses, or raw/ undercooked meat, and should be prevented from defecating around livestock. Also, contact with infected tissues of other intermediate hosts, eg, sheep, goat, horse, or feces of other domestic and wild canids, eg, coyotes or Australian dingoes, should be avoided. Discourage predation. ${ }^{20}$ Stop dogs from defecating in feeders, drinking from fountains, water sources, pastures, and corrals.

No effective vaccines to protect susceptible animals and avoid the infection are commercially available, ${ }^{20,33}$ but some effort and research has been invested in dogs and cattle. An important drawback in designing a vaccine against $N$. caninum is that the immune response itself is potentially pathogenic to the fetus. ${ }^{108}$

Vaccine research has been under way for a long time, and most approaches have focused on inactivated whole vaccines (killed tachyzoites), ${ }^{109-111}$ the use of subunit native (tachyzoite-extract vaccine formulated with a soy lecithin/ $\beta$-glucan adjuvant $)^{112,113}$ and recombinant $N$. caninum antigens, ${ }^{114-117}$ and live naturally attenuated parasites. ${ }^{118-120}$

Studies began with the use of a crude lysate of the parasite to prevent infection of offspring, followed by application in cattle and commercialization of a registered vaccine for $N$. caninum (NeoGuard ${ }^{\mathrm{TM}}$ ) for use in cattle, ${ }^{121}$ but with low efficacy $(<25 \%) .{ }^{109}$ Also, live vaccines presented higher efficacy, up to $100 \%$ in experimental infections, ${ }^{118,119}$ producing strong cellular and IFN $\gamma$ responses correlated with protection against fetopathy, but immunization with wholetachyzoite lysate using different adjuvants failed to protect against fetal death. ${ }^{118}$

A preventive vaccine based on a recombinant canine herpesvirus expressing $N$. caninum surface protein (NcSRS2), similar to the authentic parasite protein for $\operatorname{dog} s^{117}$ and cattle, ${ }^{116}$ has been tested. Nishikawa et a ${ }^{117}$ observed immunized dogs producing $N$. caninum IgG antibodies but no clinical signs, and infectious canine herpesvirus was not recovered from these dogs, whereas Staska et al ${ }^{116}$ detected parasite-specific $\mathrm{CD} 4^{+} \mathrm{T}$ lymphocytes and IFN $\gamma$ response in experimentally infected cattle, which supports further investigations of vaccines incorporating NcSRS2 gene sequences or peptides. Even with these good results, no additional further studies have been undertaken. 
In C57BL6 mice, Ramamoorthy et al ${ }^{122}$ observed protective effects of an attenuated $\gamma$-irradiated $N$. caninum tachyzoite vaccine. No vaccinated mice presented any clinical signs up to the end of the study, but showed significant increases in secreted levels of IFN $\gamma$, IL-10, $\operatorname{IgG}_{1}, \operatorname{IgG}_{2 \mathrm{a}}$, and small amounts of IL-4. Though a possibly good candidate in preventing vertical transmission in cattle, an important drawback of this vaccine may be that the irradiated tachyzoites may not persist in the host for as long as a live vaccine, ${ }^{123}$ requiring booster immunizations. ${ }^{122}$

In addition, in silica approaches open a new point of view for vaccine-candidate prediction and should be exploited; precise protein targets are paramount, and arguably the most important factor determining the success or failure of this approach. ${ }^{124}$ The same happens with drugs to prevent transplacental transmission, ${ }^{20,33}$ and new studies on these directions are required.

\section{Public health impact}

The potential of $N$. caninum to infect humans is unknown. $N$. caninum antibodies have been detected in the serum samples of immunocompetent ${ }^{54,125,126}$ and immunosuppressed humans, ${ }^{126,127}$ but no parasite isolation or detectable DNA has been reported. ${ }^{20} N$. caninum may have the potential to infect humans in the presence of HIV ${ }^{128}$ and be linked to neurological complaints, ${ }^{126}$ but while the parasite has not been linked directly to human disease, the possibility of clinically apparent $N$. caninum infections should not be dismissed. ${ }^{128}$ In this way, $N$. caninum is not considered zoonotic. ${ }^{20,41}$

\section{Future perspectives}

New insights for neosporosis and epidemiological aspects of the pathogen's evolution should be focused on the contribution of proteomics and RNA-sequencing and next-generation sequencing techniques, ie, proteogenomics. This has an important role to play in successful annotation of gene models, protein-coding genes, and allowing the validation of important proteins as potential targets for host-parasite interaction and treatment research. ${ }^{129}$ Also, gene prediction opens wide the way for vaccine candidates by bioinformatic programs. ${ }^{124}$ These and derivative approaches linked to the conventional and unconventional research, as well as diagnostic methods, will contribute to much better understanding of the parasite's evolution, biochemical interactions, parasitehost cell interaction, parasite chemical resistance, and host predisposition, as well as intrinsic properties of each strain, clones, and isolates, with regard to virulence and capacity to spread and adapt to new hosts, new targets for treatment, and possible candidates for vaccines.

\section{Final considerations}

Neosporosis is an important infection in pet and production animals. Control measures should focus on vertical and horizontal transmission to limit simultaneously environmental contamination and transmission to intermediate hosts. As the treatment response is limited to the stage of the parasite, the success of the clinical treatment increases as how early it starts, which should start before neurological pathology is observed.

\section{Author contributions}

RCS and GPM participated in all bibliography searches and contributed equally on writing and discussing the manuscript. The manuscript was written, reviewed by RCS and GPM, and edited by RCS. Both authors read and approved the final manuscript.

\section{Disclosure}

The authors report no conflicts of interest in this work.

\section{References}

1. Dubey JP. Recent advances in Neospora and neosporosis. Vet Parasitol. 1999;84(3-4):349-367.

2. Gondim LF, McAllister MM, Pitt WC, Zemlicka DE. Coyotes (Canis latrans) are definitive hosts of Neospora caninum. Int J Parasitol. 2004;34(2):159-161.

3. Dubey JP, Schares G, Ortega-Mora LM. Epidemiology and control of neosporosis and Neospora caninum. Clin Microbiol Rev. 2007; 20(2):323-367.

4. Nolan SJ, Romano JD, Luechtefeld T, Coppens I. Neospora caninum recruits host cell structures to its parasitophorous vacuole and salvages lipids from organelles. Eukaryot Cell. 2015;14(5):454-473.

5. Anderson ML, Andrianarivo AG, Conrad PA. Neosporosis in cattle. Anim Reprod Sci. 2000;60-61:417-431.

6. Dubey JP, Schares G. Neosporosis in animals - the last five years Vet Parasitol. 2011;180(1-2):90-108.

7. Bjerkås I, Mohn SF, Presthus J. Unidentified cyst-forming sporozoon causing encephalomyelitis and myositis in dogs. Z Parasitenkd. 1984;70(2):271-274.

8. Dubey JP, Carpenter JL, Speer CA, Topper MJ, Uggla A. Newly recognized fatal protozoan disease of dogs. J Am Vet Med Assoc. 1988;192(9):1269-1285.

9. Marsh AE, Barr BC, Packham AE, Conrad PA. Description of a new Neospora species (Protozoa: Apicomplexa: Sarcocystidae). J Parasitol. 1998;84(5):983-991.

10. McAllister MM, Dubey JP, Lindsay DS, Jolley WR, Wills RA, McGuire AM. Dogs are definitive hosts of Neospora caninum. Int $J$ Parasitol. 1998;28(9):1473-1478.

11. Dubey JP, Buxton D, Wouda W. Pathogenesis of bovine neosporosis J Comp Pathol. 2006;134(4):267-289.

12. Dubey JP, Lindsay DS. A review of Neospora caninum and neosporosis. Vet Parasitol. 1996;67(1-2):1-59.

13. Lindsay DS, Dubey JP, Duncan RB. Confirmation that the dog is a definitive host for Neospora caninum. Vet Parasitol. 1999;82(4) $327-333$.

14. Dubey JP, Barr BC, Barta JR, et al. Redescription of Neospora caninum and its differentiation from related coccidia. Int J Parasitol 2002;32(8):929-946.

15. Dubey JP, Leathers CW, Lindsay DS. Neospora caninum-like protozoon associated with fatal myelitis in newborn calves. J Parasitol. 1989;75(1):146-148. 
16. Barr BC, Anderson ML, Dubey JP, Conrad PA. Neospora-like protozoal infections associated with bovine abortions. Vet Pathol. 1991;28(2):110-116.

17. Dubey JP, Sreekumar C, Knickman E, et al. Biologic, morphologic, and molecular characterisation of Neospora caninum isolates from littermate dogs. Int J Parasitol. 2004;34(10):1157-1167.

18. Speer CA, Dubey JP, McAllister MM, Blixt JA. Comparative ultrastructure of tachyzoites, bradyzoites, and tissue cysts of Neospora caninum and Toxoplasma gondii. Int J Parasitol. 1999;29(10):1509-1519.

19. Hemphill A, Fuchs N, Sonda S, Hehl A. The antigenic composition of Neospora caninum. Int J Parasitol. 1999;29(8):1175-1188.

20. Sykes JE. Neosporosis. In: Sykes JE, editor. Canine and Feline Infectious Diseases. Vol 1. 1st ed. St Louis: Elsevier; 2014:704-712.

21. Lindsay DS, Dubey JP. Canine neosporosis. J Vet Parasitol. 2000;87(1):1-11.

22. Basso W, Venturini L, Venturini MC, et al. First isolation of Neospora caninum from the feces of a naturally infected dog. J Parasitol. 2001;87(3):612-618.

23. King JS, Slapeta J, Jenkins DJ, Al-Qassab SE, Ellis JT, Windsor PA. Australian dingoes are definitive hosts of Neospora caninum. Int $J$ Parasitol. 2010;40(8):945-950.

24. Dubey JP, Jenkins MC, Rajendran C, et al. Gray wolf (Canis lupus) is a natural definitive host for Neospora caninum. Vet Parasitol. 2011;181(2-4):382-387.

25. Greene CE. Toxoplasmosis and neosporosis. In: Greene CE, editor. Infectious Diseases of the Dog and Cat. 4th ed. St Louis: Elsevier; 2012:821-827.

26. Cummings JF, de Lahunta A, Suter MM, Jacobson RH. Canine protozoan polyradiculoneuritis. Acta Neuropathol. 1988;76(1):46-54.

27. Dubey JP, Lindsay DS. Neosporosis. Parasitol Today. 1993; 9(12):452-458.

28. Trees AJ, Guy F, Tennant BJ, Balfour AH, Dubey JP. Prevalence of antibodies to Neospora caninum in a population of urban dogs in England. Vet Rec. 1993;132(6):125-126.

29. Lathe CL. Neospora caninum in British dogs. Vet Rec. 1994; 134(20):532.

30. Knowler C, Wheeler SJ. Neospora caninum infection in three dogs. J Small Anim Pract. 1995;36(4):172-177.

31. Sawada M, Park CH, Kondo H, et al. Serological survey of antibody to Neospora caninum in Japanese dogs. J Vet Med Sci. 1998; 60(7):853-854.

32. Wouda W, Dijkstra T, Kramer AM, van Maanen C, Brinkhof JM. Seroepidemiological evidence for a relationship between Neospora caninum infections in dogs and cattle. Int J Parasitol. 1999;29(10): 1677-1682.

33. Dubey JP. Review of Neospora caninum and neosporosis in animals. Korean J Parasitol. 2003;41(1):1-16.

34. Almeida MA. [Epidemiology of Neospora caninum]. Rev Bras Parasitol Vet. 2004;13(Suppl 1):37-40. Portuguese.

35. Basso W, Venturini MC, Bacigalupe D, et al. Confirmed clinical Neospora caninum infection in a boxer puppy from Argentina. Vet Parasitol. 2005;131(3-4):299-303.

36. Gondim LF, McAllister MM, Gao L. Effects of host maturity and prior exposure history on the production of Neospora caninum oocysts by dogs. Vet Parasitol. 2005;134(1-2):33-39.

37. Václavek P, Sedlák K, Hůrková L, Vodrázka P, Sebesta R, Koudela B. Serological survey of Neospora caninum in dogs in the Czech Republic and a long-term study of dynamics of antibodies. Vet Parasitol. 2007;143(1):35-41.

38. Saey V, Martle V, Van Ham L, Chiers K. Neuritis of the cauda equina in a dog. J Small Anim Pract. 2010;51(10):549-552.

39. Almería S. Neospora caninum and wildlife. ISRN Parasitol. 2013;2013:947347.

40. Kul O, Atmaca HT, Anteplioglu T, Ocal N, Canpolat S. Neospora caninum: the first demonstration of the enteroepithelial stages in the intestines of a naturally infected dog. J Comp Pathol. 2015;153(1): 9-13.
41. Donahoe SL, Lindsay SA, Krockenberger M, Phalen D, Slapeta J. A review of neosporosis and pathologic findings of Neospora caninum infection in wildlife. Int J Parasitol Parasites Wildl. 2015;4(2):216-238.

42. Nascimento CO, Silva ML, Kim PC, et al. Occurrence of Neospora caninum and Toxoplasma gondii DNA in brain tissue from hoary foxes (Pseudalopex vetulus) in Brazil. Acta Trop. 2015;146:60-65.

43. Hemphill A, Gottstein B, Kaufmann H. Adhesion and invasion of bovine endothelial cells by Neospora caninum. Parasitology. 1996;1 12(Pt 2):183-197.

44. Dubey JP, Jenkins MC, Adams DS, et al. Antibody responses of cows during an outbreak of neosporosis evaluated by indirect fluorescent antibody test and different enzyme-linked immunosorbent assays. J Parasitol. 1997;83(6):1063-1069.

45. Huong LT, Ljungström BL, Uggla A, Björkman C. Prevalence of antibodies to Neospora caninum and Toxoplasma gondii in cattle and water buffaloes in southern Vietnam. Vet Parasitol. 1998;75(1):53-57.

46. Davison HC, Otter A, Trees AJ. Estimation of vertical and horizontal transmission parameters of Neospora caninum infections in dairy cattle. Int J Parasitol. 1999;29(10):1683-1689.

47. Hietala SK, Thurmond MC. Postnatal Neospora caninum transmission and transient serologic responses in two dairies. Int J Parasitol. 1999;29(10):1669-1676.

48. Atkinson R, Harper PA, Reichel MP, Ellis JT. Progress in the serodiagnosis of Neospora caninum infections of cattle. Parasitol Today. 2000;16(3):110-114.

49. Davison HC, Guy CS, McGarry JW, et al. Experimental studies on the transmission of Neospora caninum between cattle. Res Vet Sci. 2001;70(2):163-168.

50. Dijkstra T, Eysker M, Schares G, Conraths FJ, Wouda W, Barkema HW. Dogs shed Neospora caninum oocysts after ingestion of naturally infected bovine placenta but not after ingestion of colostrum spiked with Neospora caninum tachyzoites. Int J Parasitol. 2001;31(8): 747-752.

51. Morales E, Trigo FJ, Ibarra F, Puente E, Santacruz M. Neosporosis in Mexican dairy herds: lesions and immunohistochemical detection of Neospora caninum in fetuses. J Comp Pathol. 2001;125(1):58-63.

52. Guimaraes JS Jr, Souza SL, Bergamaschi DP, Gennari SM. Prevalence of Neospora caninum antibodies and factors associated with their presence in dairy cattle of the north of Parana state, Brazil. Vet Parasitol. 2004;124(1-2):1-8.

53. Konnai S, Mingala CN, Sato M, et al. A survey of abortifacient infectious agents in livestock in Luzon, the Philippines, with emphasis on the situation in a cattle herd with abortion problems. Acta Trop. 2008;105(3):269-273.

54. Ibrahim HM, Huang P, Salem TA, et al. Short report: prevalence of Neospora caninum and Toxoplasma gondii antibodies in northern Egypt. Am J Trop Med Hyg. 2009;80(2):263-267.

55. Reichel MP, Ellis JT. Neospora caninum - how close are we to development of an efficacious vaccine that prevents abortion in cattle? Int J Parasitol. 2009;39(11):1173-1187.

56. Boas RV, Pacheco TA, Melo AL, Oliveira AC, Aguiar DM, Pacheco RC. Infection by Neospora caninum in dairy cattle belonging to family farmers in the northern region of Brazil. Rev Bras Parasitol Vet. 2015;24(2):204-208.

57. Campero LM, Minke L, More G, et al. Evaluation and comparison of serological methods for the detection of bovine neosporosis in Argentina. Rev Argent Microbiol. 2015;47(4):295-301.

58. Fort M, Edelsten M, Maley S, Innes E. Seroepidemiological study of Neospora caninum in beef and dairy cattle in La Pampa, Argentina. Acta Parasitol. 2015;60(2):275-282.

59. Neverauskas CE, Nasir A, Reichel MP. Prevalence and distribution of Neospora caninum in water buffalo (Bubalus bubalis) and cattle in the Northern Territory of Australia. Parasitol Int. 2015;64(5):392-396.

60. Nasir A, Ashraf M, Khan MS, et al. Seroprevalence of Neospora caninum in dairy buffaloes in Lahore District, Pakistan. J Parasitol. 2011;97(3):541-543. 
61. Auriemma C, Lucibelli MG, Borriello G, et al. PCR detection of Neospora caninum in water buffalo foetal tissues. Acta Parasitol. 2014;59(1):1-4.

62. Chryssafidis AL, Canton G, Chianini F, et al. Abortion and foetal lesions induced by Neospora caninum in experimentally infected water buffalos (Bubalus bubalis). Parasitol Res. 2015;114(1):193-199.

63. Liu ZK, Li JY, Pan H. Seroprevalence and risk factors of Toxoplasma gondii and Neospora caninum infections in small ruminants in China. Prev Vet Med. 2015;118(4):488-492.

64. Kengradomkij C, Inpankaew T, Kamyingkird K, et al. Seroprevalence and risk factors associated with exposure of water buffalo (Bubalus bubalis) to Neospora caninum in northeast Thailand. Vet Parasitol. 2015;207(1-2):156-160.

65. Reichel MP, McAllister MM, Nasir A, Moore DP. A review of Neospora caninum in water buffalo (Bubalus bubalis). Vet Parasitol. 2015;212(3-4):75-79.

66. Soares HS, Ahid SM, Bezerra AC, Pena HF, Dias RA, Gennari SM. Prevalence of anti-Toxoplasma gondii and anti-Neospora caninum antibodies in sheep from Mossoro, Rio Grande do Norte, Brazil. Vet Parasitol. 2009;160(3-4):211-214.

67. Abo-Shehada MN, Abu-Halaweh MM. Flock-level seroprevalence of, and risk factors for, Neospora caninum among sheep and goats in northern Jordan. Prev Vet Med. 2010;93(1):25-32.

68. Langoni H, Greca H Jr, Guimaraes FF, et al. Serological profile of Toxoplasma gondii and Neospora caninum infection in commercial sheep from São Paulo State, Brazil. Vet Parasitol. 2011;177(1-2):50-54.

69. Nasir A, Ashraf M, Khan MS, et al. Prevalence of Neospora caninum antibodies in sheep and goats in Pakistan. J Parasitol. 2012;98(1): 213-215

70. Anastasia D, Elias P, Nikolaos P, Charilaos K, Nektarios G. Toxoplasma gondii and Neospora caninum seroprevalence in dairy sheep and goats mixed stock farming. Vet Parasitol. 2013;198(3-4):387-390.

71. Paiz LM, Silva RC, Menozzi BD, Langoni H. Antibodies to Neospora caninum in sheep from slaughterhouses in the state of São Paulo, Brazil Rev Bras Parasitol Vet. 2015;24(1):95-100.

72. Modolo JR, Stachissini AV, Gennari SM, et al. Frequency of antibodies anti-Neospora caninum in sera of goats of the state São Paulo and its relationship with flock management. Pesq Vet Bras. 2008;28(12):597-600.

73. Czopowicz M, Kaba J, Szalus-Jordanow O, Nowicki M, Witkowski L, Frymus T. Seroprevalence of Toxoplasma gondii and Neospora caninum infections in goats in Poland. Vet Parasitol. 2011;178(3-4):339-341.

74. Jung BY, Lee SH, Kwak D. Evidence of Neospora caninum exposure among native Korean goats (Capra hircus coreanae). Vet Med 2014;59(12):637-640.

75. Lindsay DS, Steinberg H, Dubielzig RR, et al. Central nervous system neosporosis in a foal. J Vet Diagn Invest. 1996;8(4):507-510.

76. Bartova E, Machacova T, Sedlak K, Budikova M, Mariani U, Veneziano V. Seroprevalence of antibodies of Neospora spp. and Toxoplasma gondii in horses from southern Italy. (Folia Parasitol Praha). 2015;62:043.

77. Galvao CM, Rezende-Gondim MM, Chaves AC, Schares G, Ribas JR, Gondim LF. Brazilian donkeys (Equus asinus) have a low exposure to Neospora spp. Rev Bras Parasitol Vet. 2015;24(3):340-344.

78. Dubey JP, Lindsay DS, Hill D, et al. Prevalence of antibodies to Neospora caninum and Sarcocystis neurona in sera of domestic cats from Brazil. J Parasitol. 2002;88(6):1251-1252.

79. King JS, Vaughan JL, Windsor PA. Serological evidence of Neospora caninum in alpacas from eastern Australia. Aust Vet J. 2015;93(7): 259-261.

80. Du L, Yang D, Zhai T, Gong P, Zhang X, Li J. Detection of Neospora caninum-DNA in brain tissues from pigeons in Changchun, Jilin (China). Vet Parasitol. 2015;214(1-2):171-173.

81. Salant H, Mazuz ML, Savitsky I, Nasereddin A, Blinder E, Baneth G. Neospora caninum in crows from Israel. Vet Parasitol. 2015;212(3-4):375-378.

82. Quinn HE, Ellis JT, Smith NC. Neospora caninum: a cause of immunemediated failure of pregnancy? Trends Parasitol. 2002;18(9):391-394.
83. Hemphill A, Vonlaufen N, Naguleswaran A. Cellular and immunological basis of the host-parasite relationship during infection with Neospora caninum. Parasitology. 2006;133(Pt 3):261-278.

84. Williams DJ, Hartley CS, Björkman C, Trees AJ. Endogenous and exogenous transplacental transmission of Neospora caninum - how the route of transmission impacts on epidemiology and control of disease. Parasitology. 2009;136(14):1895-1900.

85. Zachary JF, McGavin MD. Pathologic Basis of Veterinary Disease. 5th ed. St Louis: Elsevier; 2012.

86. Buxton D, McAllister MM, Dubey JP. The comparative pathogenesis of neosporosis. Trends Parasitol. 2002;18(12):546-552.

87. Romano JD, Sonda S, Bergbower E, Smith ME, Coppens I. Toxoplasma gondii salvages sphingolipids from the host Golgi through the rerouting of selected Rab vesicles to the parasitophorous vacuole. Mol Biol Cell. 2013;24(12):1974-1995.

88. Jordan KA, Hunter CA. Regulation of CD8+ T cell responses to infection with parasitic protozoa. Exp Parasitol. 2010;126(3):318-325.

89. Jordan KA, Wilson EH, Tait ED, et al. Kinetics and phenotype of vaccine-induced CD8+ T-cell responses to Toxoplasma gondii. Infect Immun. 2009;77(9):3894-3901.

90. Correia A, Ferreirinha P, Botelho S, et al. Predominant role of interferon- $\gamma$ in the host protective effect of CD8(+) T cells against Neospora caninum infection. Sci Rep. 2015;5:14913.

91. Lindsay DS, Dubey JP. Immunohistochemical diagnosis of Neospora caninum in tissue sections. Am J Vet Res. 1989;50(11):1981-1983.

92. Campero LM, Venturini MC, Moore DP, et al. Isolation and molecular characterization of a new Neospora caninum isolate from cattle in Argentina. Exp Parasitol. 2015;155:8-12.

93. van Maanen C, Wouda W, Schares G, et al. An interlaboratory comparison of immunohistochemistry and PCR methods for detection of Neospora caninum in bovine foetal tissues. Vet Parasitol. 2004; 126(4):351-364.

94. Baszler TV, Gay LJ, Long MT, Mathison BA. Detection by PCR of Neospora caninum in fetal tissues from spontaneous bovine abortions. J Clin Microbiol. 1999;37(12):4059-4064.

95. Sanchez GF, Banda RV, Sahagun RA, Ledesma MN, Morales SE. Comparison between immunohistochemistry and two PCR methods for detection of Neospora caninum in formalin-fixed and paraffinembedded brain tissue of bovine fetuses. Vet Parasitol. 2009 164(2-4):328-332.

96. Björkman C, Uggla A. Serological diagnosis of Neospora caninum infection. Int J Parasitol. 1999;29(10):1497-1507.

97. Camargo ME. [Introduction to immunofluorescence techniques] Rev Bras Patol Clin. 1974;10(3):87-107. Portuguese.

98. Romand S, Thulliez P, Dubey JP. Direct agglutination test for serologic diagnosis of Neospora caninum infection. Parasitol Res. 1998;84(1):50-53.

99. Alvarez-Garcia G, Pereira-Bueno J, Gomez-Bautista M, OrtegaMora LM. Pattern of recognition of Neospora caninum tachyzoite antigens by naturally infected pregnant cattle and aborted foetuses. Vet Parasitol. 2002;107(1-2):15-27.

100. Alvarez-Garcia G, Garcia-Culebras A, Gutiérrez-Expósito D, NavarroLozano V, Pastor-Fernández I, Ortega-Mora LM. Serological diagnosis of bovine neosporosis: a comparative study of commercially available ELISA tests. Vet Parasitol. 2013;198(1-2):85-95.

101. Björkman C, Alvarez-Garcia G, Conraths FJ, et al. Neospora caninum IgG avidity tests: an interlaboratory comparison. Vet Parasitol. 2006;140(3-4):273-280.

102. Waldner CL, Cunningham G, Campbell JR. Agreement between three serological tests for Neospora caninum in beef cattle. J Vet Diagn Invest. 2004;16(4):313-315.

103. Dubey JP, Vianna MC, Kwok OC, et al. Neosporosis in beagle dogs: clinical signs, diagnosis, treatment, isolation and genetic characterization of Neospora caninum. Vet Parasitol. 2007;149(3-4): 158-166.

104. Mehlhorn H. Encyclopedic Reference of Parasitology: Diseases, Treatment, Therapy. 2nd ed. Berlin: Springer; 2001. 
105. Lindsay DS, Butler JM, Rippey NS, Blagburn BL. Demonstration of synergistic effects of sulfonamides and dihydrofolate reductase/ thymidylate synthase inhibitors against Neospora caninum tachyzoites in cultured cells, and characterization of mutants resistant to pyrimethamine. Am J Vet Res. 1996;57(1):68-72.

106. Lindsay DS, Rippey NS, Cole RA, et al. Examination of the activities of 43 chemotherapeutic agents against Neospora caninum tachyzoites in cultured cells. Am J Vet Res. 1994;55(7):976-981.

107. Crookshanks JL, Taylor SM, Haines DM, Shelton GD. Treatment of canine pediatric Neospora caninum myositis following immunohistochemical identification of tachyzoites in muscle biopsies. Can VetJ. 2007;48(5):506-508.

108. Williams DJ, Trees AJ. Protecting babies: vaccine strategies to prevent foetopathy in Neospora caninum-infected cattle. Parasite Immunol. 2006;28(3):61-67.

109. Weston JF, Heuer C, Williamson NB. Efficacy of a Neospora caninum killed tachyzoite vaccine in preventing abortion and vertical transmission in dairy cattle. Prev Vet Med. 2012;103(2-3):136-144.

110. Andrianarivo AG, Rowe JD, Barr BC, et al. A Polygen-adjuvanted killed Neospora caninum tachyzoite preparation failed to prevent foetal infection in pregnant cattle following i.v./i.m. experimental tachyzoite challenge. Int J Parasitol. 2000;30(9):985-990.

111. Romero JJ, Perez E, Frankena K. Effect of a killed whole Neospora caninum tachyzoite vaccine on the crude abortion rate of Costa Rican dairy cows under field conditions. Vet Parasitol. 2004;123(3-4): 149-159.

112. Mansilla FC, Czepluch W, Malacari DA, et al. Dose-dependent immunogenicity of a soluble Neospora caninum tachyzoite-extract vaccine formulated with a soy lecithin/ $\beta$-glucan adjuvant in cattle. Vet Parasitol. 2013;197(1-2):13-21.

113. Mansilla FC, Moore DP, Quintana ME, et al. Safety and immunogenicity of a soluble native Neospora caninum tachyzoite-extract vaccine formulated with a soy lecithin/ $\beta$-glucan adjuvant in pregnant cattle. Vet Immunol Immunopathol. 2015;165(1-2):75-80.

114. Uchida M, Nagashima K, Akatsuka Y, et al. Comparative study of protective activities of Neospora caninum bradyzoite antigens, NcBAG1, NcBSR4, NcMAG1, and NcSAG4, in a mouse model of acute parasitic infection. Parasitol Res. 2013;112(2):655-663.

115. Hecker YP, Coceres V, Wilkowsky SE, et al. A Neospora caninum vaccine using recombinant proteins fails to prevent foetal infection in pregnant cattle after experimental intravenous challenge. Vet Immunol Immunopathol. 2014;162(3-4):142-153.

116. Staska LM, Davies CJ, Brown WC, et al. Identification of vaccine candidate peptides in the NcSRS2 surface protein of Neospora caninum by using CD4+ cytotoxic T lymphocytes and gamma interferonsecreting $\mathrm{T}$ lymphocytes of infected Holstein cattle. Infect Immun. 2005;73(3):1321-1329.
117. Nishikawa $Y$, Ikeda $H$, Fukumoto $S$, et al. Immunization of dogs with a canine herpesvirus vector expressing Neospora caninum surface protein, NcSRS2. Int J Parasitol. 2000;30(11):1167-1171.

118. Williams DJ, Guy CS, Smith RF, et al. Immunization of cattle with live tachyzoites of Neospora caninum confers protection against fetal death. Infect Immun. 2007;75(3):1343-1348.

119. Weber FH, Jackson JA, Sobecki B, et al. On the efficacy and safety of vaccination with live tachyzoites of Neospora caninum for prevention of Neospora-associated fetal loss in cattle. Clin Vaccine Immunol. 2013;20(1):99-105.

120. Reichel MP, Moore DP, Hemphill A, Ortega-Mora LM, Dubey JP, Ellis JT. A live vaccine against Neospora caninum abortions in cattle. Vaccine. 2015;33(11):1299-1301.

121. Reichel MP, McAllister MM, Pomroy WE, Campero C, OrtegaMora LM, Ellis JT. Control options for Neospora caninum - is there anything new or are we going backwards? Parasitology. 2014;141(11):1455-1470.

122. Ramamoorthy S, Lindsay DS, Schurig GG, et al. Vaccination with $\gamma$-irradiated Neospora caninum tachyzoites protects mice against acute challenge with $N$. caninum. J Eukaryot Microbiol. 2006;53(2):151-156.

123. Lindsay DS, Lenz SD, Blagburn BL, Brake DA. Characterization of temperature-sensitive strains of Neospora caninum in mice. J Parasitol. 1999;85(1):64-67.

124. Goodswen SJ, Barratt JL, Kennedy PJ, Ellis JT. Improving the gene structure annotation of the apicomplexan parasite Neospora caninum fulfils a vital requirement towards an in silico-derived vaccine. Int $J$ Parasitol. 2015;45(5):305-318.

125. Tranas J, Heinzen RA, Weiss LM, McAllister MM. Serological evidence of human infection with the protozoan Neospora caninum. Clin Diagn Lab Immunol. 1999;6(5):765-767.

126. Lobato J, Silva DA, Mineo TW, et al. Detection of immunoglobulin G antibodies to Neospora caninum in humans: high seropositivity rates in patients who are infected by human immunodeficiency virus or have neurological disorders. Clin Vaccine Immunol. 2006;13(1):84-89.

127. Oshiro LM, Motta-Castro AR, Freitas SZ, et al. Neospora caninum and Toxoplasma gondii serodiagnosis in human immunodeficiency virus carriers. Rev Soc Bras Med Trop. 2015;48(5):568-572.

128. Barratt JL, Harkness J, Marriott D, Ellis JT, Stark D. Importance of nonenteric protozoan infections in immunocompromised people. Clin Microbiol Rev. 2010;23(4):795-836.

129. Krishna R, Xia D, Sanderson S, et al. A large-scale proteogenomics study of apicomplexan pathogens - Toxoplasma gondii and Neospora caninum. Proteomics. 2015;15(15):2618-2628.
Veterinary Medicine: Research and Reports

\section{Publish your work in this journal}

Veterinary Medicine: Research and Reports is an international, peer-reviewed, open access journal publishing original research, case reports, editorials, reviews and commentaries on all areas of veterinary medicine. The manuscript management system is completely online and includes a very quick and fair peer-review system.

\section{Dovepress}

Visit http://www.dovepress.com/testimonials.php to read real quotes from published authors. 